\title{
Comparison of an oral and an intravenous feeding regimen in the newborn
}

\author{
R. W. LOGAN, D. G. YOUNG, D. A. ROSS, B. R. STEWART, M. KUBO, and G. TRYFONAS
} From the Departments of Biochemistry and Paediatric Surgery, Royal Hospital for Sick Children, Glasgow

\begin{abstract}
Logan, R. W., Young, D. G., Ross, D. A., Stewart, B. R., Kubo, M., and Tryfonas, G. (1974). Archives of Disease in Childhood, 49, 200. Comparison of an oral and an intravenous feeding regimen in the newborn. In a series of neonates undergoing comparable operations which did not affect the alimentary tract, the relative merits of similar oral and intravenous feeding regimens were compared. Metabolic balance studies were performed, together with measurement of plasma and urinary amino acids. Though the clinical response to both regimens was satisfactory, it was found that, in the group fed intravenously, certain of the plasma and urinary amino acids attained concentrations outside normal limits. This was almost certainly due to the nature of the amino acid solution infused.
\end{abstract}

With the development of numerous solutions of amino acids, carbohydrate, and fat suitable for intravenous infusion, the ability to sustain life by the administration of these solutions has become feasible (Wilmore et al., 1969). The value of intravenous feeding in the newborn, who has undergone operation which precludes feeding by the alimentary tract, has been shown to be life-saving (Asch, Huxtable, and Hays, 1972), but the value of intravenous feeding in the postoperative phase has yet to be defined (Johnston, Tweedle, and Spivey, 1972). Doubt exists about the utilization of solutions administered intravenously (Jarnum et al., 1969; Larsen and Brockner, 1969), and it is important to determine if intravenous feeding will produce a better anabolic response after operation as compared with that achieved by the gradual reintroduction of oral feeding.

This study was performed in a series of infants undergoing comparable operations which did not affect the alimentary tract. Two groups are compared, one with an oral diet and the other with an intravenous feeding regimen yielding comparable fluid, calorie, mineral, and vitamin intakes. Balance studies were made on these patients.

\section{Subjects and methods}

Patients admitted in the first 24 hours of life on account of meningocele or myelomeningocele, in whom early operation was indicated, were selected. The

Received 12 September 1973. procedures were explained to the parents and only in those cases where parental consent was obtained were the studies undertaken.

Alternate patients were given oral or intravenous feeding regimens. The infants were subdivided into three groups by birthweight, $<2.5 \mathrm{~kg}, 2.5$ to $3.5 \mathrm{~kg}$, and $3.5 \mathrm{~kg}$ and over. The feeding regimens were adapted to the needs of the different birthweight groups. In both groups (oral 7 cases, intravenous 6 cases) only glucose was administered as from 8.00 a.m. on the morning after operation, the oral group being fed 3-hourly. Thereafter, those fed orally received Ostermilk No. $1,{ }^{\star}$ and the intravenous regimen comprised Trophysan $5, \star$ laevulose $10 \%$, and Lipiphysan $10 \%$ * in a 3-hourly cycle, each solution being given for 1 hour. Details of the oral and intravenous schedules are shown in Tables I and II. Table III lists the calories supplied by the oral and

TABLE I

Oral feeding regimen

\begin{tabular}{|c|c|c|c|c|}
\hline \multirow{2}{*}{ Day } & \multirow{2}{*}{ Feed } & \multicolumn{3}{|c|}{ Birthweight } \\
\hline & & $<2.5 \mathrm{~kg}$ & $2 \cdot 5-3 \cdot 5 \mathrm{~kg}$ & $z 3.5 \mathrm{~kg}$ \\
\hline $\begin{array}{l}1 \\
2 \\
3 \\
4 \\
5 \\
6 \\
7\end{array}$ & $\begin{array}{l}\text { Dextrose (ml) } \\
\text { Ostermilk No. } 1(\mathrm{ml}) \\
\text { Ostermilk No. } 1(\mathrm{ml}) \\
\text { Ostermilk No. } 1(\mathrm{ml}) \\
\text { Ostermilk No. } 1(\mathrm{ml}) \\
\text { Ostermilk No. } 1(\mathrm{ml}) \\
\text { Ostermilk No. } 1(\mathrm{ml})\end{array}$ & $\begin{array}{l}120 \\
144 \\
192 \\
240 \\
288 \\
360 \\
360\end{array}$ & $\begin{array}{l}144 \\
192 \\
240 \\
288 \\
360 \\
480 \\
480\end{array}$ & $\begin{array}{l}192 \\
240 \\
288 \\
360 \\
480 \\
520 \\
520\end{array}$ \\
\hline
\end{tabular}

$\star$ Ostermilk No. 1, cow's milk formula. Trophysan 5 and Lipiphysan $10 \%$ manufactured by Servier Laboratories Ltd., Percival House, Pinner Road, Harrow, Middlesex. 
TABLE II

Intravenous feeding regimen

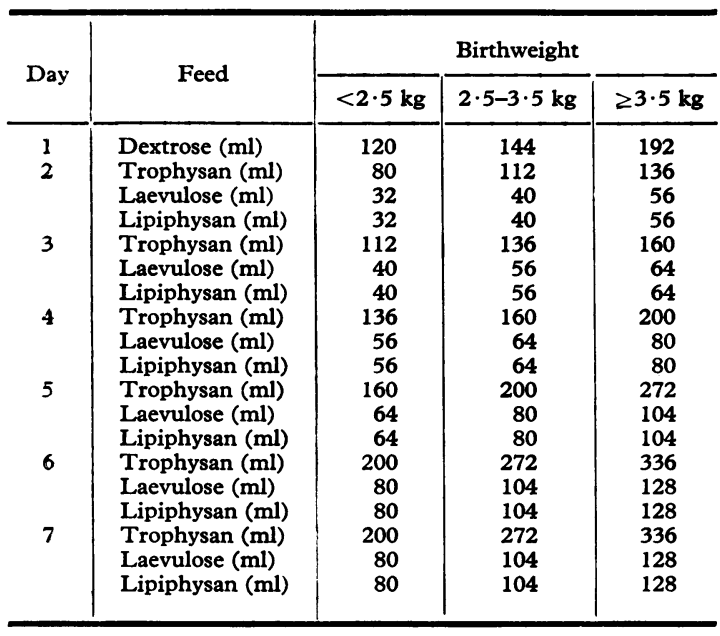

intravenous routes, and typically the regimens supplied an average of $2.8 \mathrm{~g}$ protein $/ \mathrm{kg}$ per day and $70 \mathrm{cal} / \mathrm{kg}$ per day during the period of study. In order to obtain similarity of vitamin and mineral intakes, the intravenous regimen was supplemented as shown in Table IV, the multivitamin preparation ${ }^{\star}$ containing in particular vitamins $\mathrm{A}, \mathrm{B}, \mathrm{C}, \mathrm{D}$, and $\mathrm{E}$. In addition, calcium glycerophosphate powders were given orally in a dose ( $420 \mathrm{mg} / 100 \mathrm{ml}$ intravenous regimen) designed to match the calcium intake in the milk.

Administration of the intravenous fluids was facilitated by use of scalp vein needles into small peripheral veins. The infusions were controlled using IVAC infusion pumps with millipore filters in the line supplying the Trophysan and laevulose solutions, but not in that carrying the Lipiphysan. Deviations from the desired inputs were recorded and taken into account in the ultimate assessment.

All specimens of faeces, urine, and rejected diet were collected. Faecal collections continued until a carmine marker given at the end of the trial period appeared. Analyses were performed for determination of total nitrogen balance, faecal fat excretion, and urinary total

*Multi-Vitamin Infusion, U.S.V. Pharmaceuticals Corp., Tuckahoe, N.Y., U.S.A.; imported by T. J. Sas Ltd., London.

\section{TABLE IV}

\section{Supplements to intravenous regimen}

To each $500 \mathrm{ml} \mathrm{10 \%} \mathrm{laevulose} \mathrm{were} \mathrm{added}$

(1) $10 \mathrm{ml} 5 \%$ sodium chloride

(2) $10 \mathrm{ml} 10 \%$ potassium chloride

(3) $10 \mathrm{ml}$ (1 ampoule) multivitamin infusion

(4) $20 \mathrm{ml}$ 'dilute iron' solution (Imferon $0.2 \mathrm{mg} \mathrm{Fe} / \mathrm{ml}$ )

To each $500 \mathrm{ml}$ Trophysan 5 were added

(1) $10 \mathrm{ml} 5 \%$ sodium chloride

(2) $10 \mathrm{ml} 10 \%$ potassium chloride

nitrogen and free $\alpha$ amino nitrogen outputs. In addition, on days 1 and 7 urine specimens were processed to measure individual amino acid outputs. A blood sample $(3 \mathrm{ml})$ was withdrawn on days 1 and 7 to permit measurement of electrolytes, urea, and creatinine, acid-base studies, liver function tests, and plasma amino acid concentrations. Where possible, a daily record of body weight was maintained in all patients. The nitrogen content of the faeces, urine, and diet was determined by a micro Kjeldahl procedure and faecal fat by a modification of the technique of van de Kamer, ten Bokkel Huinink, and Weyers (1949). In addition, the nitrogen content of Ostermilk No. 1 and Trophysan 5 was measured on more than one occasion to ensure that the values published by the manufacturers could be taken as accurate in subsequent calculations. Plasma electrolytes, calcium, phosphorus, and liver function tests were determined using a Technicon SMA 12/Micro AutoAnalyzer as described by Logan and Tweedie (1973), and determination of acid-base status by means of Radiometer (Astrup) equipment. Urinary total free $\alpha$ amino nitrogen excretion was analysed by the method of Rubinstein and Pryce (1959), and plasma and urinary amino acids were measured after deproteinization of $1 \mathrm{ml}$ samples with $200 \mathrm{mg}$ salicylsulphonic acid, by means of a Technicon TSM I amino acid analyser.

\section{Results}

In Table $\mathrm{V}$ are listed the plasma and urinary amino acid findings from the study. For the purpose of the Discussion, those amino acids considered essential or semi-essential in infants and adults are shown, as well as the amino acids contained in Trophysan.

Table VI summarizes the results of the study.

TABLE III

Origin of calorie intake

\begin{tabular}{|c|c|c|c|c|}
\hline \multirow{2}{*}{ Regimen } & \multirow{2}{*}{ Calories $/ 100 \mathrm{ml}$} & \multicolumn{3}{|c|}{ Percentage of calories derived from } \\
\hline & & Fat & Carbohydrate & Protein \\
\hline
\end{tabular}




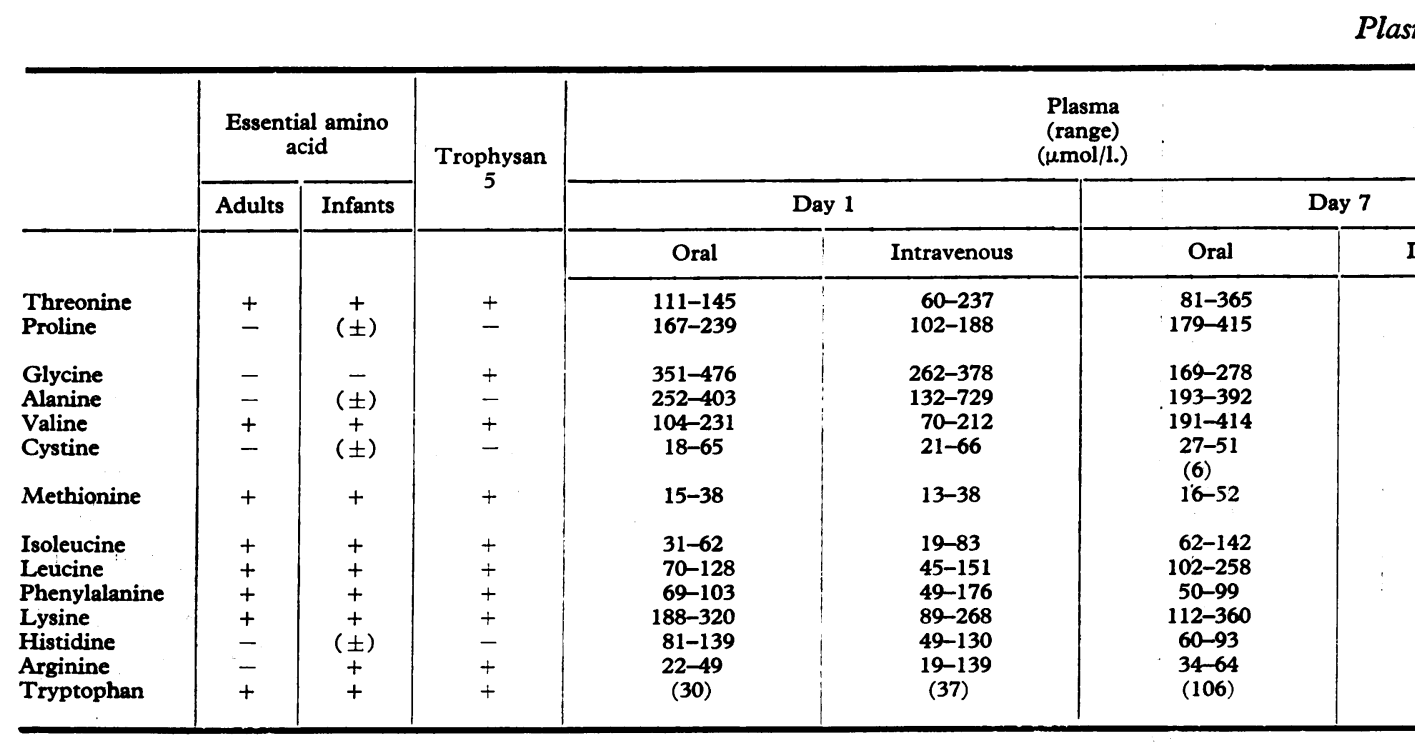

Note: Parentheses indicate one result recorded. ND, none detected.

\section{Discussion}

The results from the study answer many of the questions presented at the outset, but leave other problems unresolved. From Table VI it can be seen that though the urinary free $\alpha$ amino nitrogen in the intravenous group was greatly in excess of the results in those fed orally, the faecal nitrogen excretion was correspondingly lower, resulting in similar overall nitrogen balances. As would be expected, the faecal fat excretion tended to be less in those receiving the intravenous regimen. Since the initial state of hydration varied between cases, it was found that any change in weight over the period did not necessarily correlate with the nitrogen balance.

As far as individual amino acid concentrations are concerned, it was found (Table V) that on day 7 the plasma specimens from the intravenous group showed a conspicuous rise in glycine, methionine, leucine, and phenylalanine, with reductions of isoleucine and, to a lesser degree, of proline, cystine, and histidine. It is interesting to recall that proline (Harries et al., 1971), cystine (Sturman, Gaull, and Raiha, 1970), and histidine (Holt, 1967) have all been cited as being necessary for optimal nitrogen retention in infants. The plasma concentrations of arginine and alanine (Jürgens and Dolif, 1968), which may also be 'semi-essential' were, however, within normal limits. The rise in plasma glycine was not entirely unexpected since approximately $60 \%$ of the amino acid content of Trophysan is present as glycine. All those amino acids found to be increased in the plasma were also present in excess in the urine specimens collected on day 7 . In addition, however, the urinary outputs of valine,

TABLE VI

Summary of findings

\begin{tabular}{|c|c|c|}
\hline & Oral regimen & Intravenous regimen (Trophysan 5) \\
\hline $\begin{array}{l}\text { Change in weight }(\mathrm{kg} / 7 \mathrm{dy}) \\
\text { Faecal fat }(\mathrm{g} / 24 \mathrm{hr}) \\
\text { Faecal nitrogen }(\mathrm{mg} / 7 \mathrm{dy}) \\
\text { Urine nitrogen }(\mathrm{mg} / 7 \mathrm{dy}) \\
\% \text { free } \alpha \mathrm{NH}_{2} \\
\text { Range (per } 7 \mathrm{dy}) \\
\text { Maximum (in } 1 \mathrm{dy}) \\
\text { Nitrogen balance }(\mathrm{mg} / \mathrm{kg} \text { per } 7 \mathrm{dy}) \\
\text { Urine creatinine }(\mathrm{mg} / 7 \mathrm{dy})\end{array}$ & $\begin{array}{c}(-0 \cdot 07)-(+0 \cdot 35) \\
0 \cdot 71-2 \cdot 7 \\
675-1800 \\
1153-4495 \\
1 \cdot 9-4 \cdot 5 \\
5 \cdot 0 \\
+750-+1750 \\
59-234\end{array}$ & $\begin{array}{c}(-0 \cdot 26)-(+0 \cdot 17) \\
0 \cdot 10-1 \cdot 03 \\
352-594 \\
1972-4532 \\
\\
11 \cdot 8-22 \cdot 7 \\
34 \cdot 3 \\
+890-+1650 \\
102-195\end{array}$ \\
\hline
\end{tabular}




\begin{tabular}{|c|c|c|c|}
\hline \multicolumn{4}{|c|}{$\begin{array}{c}\text { Urine } \\
\text { (range) } \\
\text { ( } \mu \mathrm{mol} / \mathrm{g} \text { creatinine })\end{array}$} \\
\hline \multicolumn{2}{|c|}{ Day 1} & \multicolumn{2}{|c|}{ Day 7} \\
\hline Oral & Intravenous & Oral & Intravenous \\
\hline $\begin{array}{c}37-718 \\
135-470 \\
\text { (ND) } \\
255-5750 \\
52-990 \\
9-288 \\
20-720\end{array}$ & $\begin{array}{c}71-197 \\
41-284 \\
(\mathrm{ND}) \\
211-2260 \\
140-438 \\
28-147 \\
100-490\end{array}$ & $\begin{array}{c}234-3790 \\
\text { ND-3440 } \\
\\
366-10,900 \\
93-2380 \\
111-628 \\
\text { ND-575 }\end{array}$ & $\begin{array}{c}25,600-36,000 \\
\text { ND-2480 } \\
45,400-235,000 \\
710-3790 \\
27,700-42,900 \\
172-693\end{array}$ \\
\hline $\begin{array}{c}42-221 \\
(1370)\end{array}$ & $13-71$ & $52-720$ & $1495-20,230$ \\
\hline $\begin{array}{c}170-313 \\
24-691 \\
20-224 \\
21-1950 \\
83-2720 \\
18-227 \\
-\end{array}$ & $\begin{array}{c}45-160 \\
39-77 \\
20-102 \\
38-1475 \\
101-512 \\
38-102 \\
13 ; 186\end{array}$ & $\begin{array}{c}52-275 \\
92-425 \\
168-342 \\
274-2650 \\
149-3470 \\
137-435 \\
(144)\end{array}$ & $\begin{array}{c}109-845 \\
15,100-27,200 \\
14,700-27,100 \\
1760-9330 \\
\text { ND-5900 } \\
\text { ND-2220 } \\
2840-10,000\end{array}$ \\
\hline
\end{tabular}

threonine, tryptophan, and to a minor extent lysine, were increased above those in the group fed orally. The precise reasons for those findings are not known, but it is likely that a large proportion of the amino acids present in the $\mathrm{D}$-form would be excreted (Milne, 1968), though it has been reported that D-phenylalanine and D-methionine can be at least partly utilized in the body (Rose, 1949). Giordano et al. (1972) also have stated that the known enhancement of nitrogen balance produced by administration of $\mathrm{D}$-amino acids could be interpreted as an increase in protein synthesis involving as intermediates the ketoacid analogues of the D-amino acids. Supporting the suggested urinary loss of the $D$-amino acids is the observation that only moderate amounts of lysine and arginine were excreted and these amino acids are present in Trophysan only in the $\mathbf{L}$-form.

The composition of Trophysan is such that about $14 \%$ of the amino acids are present in the D-form and it is interesting to note that the percentage of urinary total nitrogen excreted as free $\alpha$ amino nitrogen never averaged less than about $12 \%$ during the study and exceeded $30 \%$ on one occasion. The abnormally high result could be due to inhibition of renal tubular reabsorption of certain amino acids caused by increased filtered loads of others being presented to the tubules. Whatever the mechanism may be, it is obviously wasteful and undesirable to have such abnormalities in the plasma (Ghadimi $e t$ al. 1971; Ghadimi, 1973) and urine. It is not considered that this situation could have been radically altered by varying the intravenous regimen while still using Trophysan 5 , though it must be stressed that the schedule administered was to some extent arbitrary and not necessarily the most effective in treating all cases. Using a different scheme, Borreson, Coran, and Knutrud (1970) employed an L-amino acid solution (Aminofusin L-Forte) with satisfactory results, and Johnston (1972) advocated the use of solutions containing only L-amino acids, while Monnens et al. (1973) found the L-amino acid preparation Vamin suitable for infants.

In spite of potential shortcomings, however, the infants fed intravenously showed satisfactory clinical response over the short period of this study, displaying only minimal signs of complications such as thrombophlebitis and hyperlipaemia. A mild hyperchloraemic acidosis was observed on day 7 in only 2 of the subjects receiving the intravenous therapy and this could possibly have been caused by using only laevulose and sorbitol as sources of carbohydrate (Harries, 1971). Biochemical impairment of liver function, marked metabolic acidosis, or severe hyperlipaemia were features not observed. Our investigations lead us to conclude that balanced feeding in the neonate exclusively by intravenous means can produce very satisfactory results. In the infants studied, however, using the regimens described, the intravenous feeding conferred no advantage over oral feeding. In agreement with a 
study reported in adults (Tweedle, Spivey, and Johnston, 1971), the detailed findings suggest that the intravenous regimen used may be improved by supplying the amino acids in the form of one of the pure L-amino acid solutions now commercially available.

We express our appreciation to members of the nursing staff without whose co-operation the investigations could not have been undertaken. We also thank Servier Laboratories for financial support which enabled the study to be performed.

\section{REFERENCES}

Asch, M. J., Huxtable, R. F., and Hays, D. M. (1972). High calorie parenteral therapy in infants and children. Archives of Surgery, 104, 434.

Borreson, H. C., Coran, A. G., and Knutrud, O. (1970). Metabolic results of parenteral feeding in neonatal surgery. Annals of Surgery, 172, 291.

Ghadimi, H. (1973). Acid-base problems after intravenous amino acids. New England Fournal of Medicine, 288, 420.

Ghadimi, H., Abaci, F., Kumar, S., and Rathi, M. (1971). Biochemical aspects of intravenous alimentation. Pediatrics, 48 , 955.

Giordano, C., Phillips, M. E., De Pascale, C., De Santo, N. G., Fürst, P., Brown, C. L., Houghton, B. J., and Richards, P. (1972). Utilisation of ketoacid analogues of valine and phenylalanine in health and uraemia. Lancet, 1, 178.

Harries, J. T. (1971). Intravenous feeding in infants. Archives of Disease in Childhood, 46, 855.

Harries, J. T., Piesowicz, A. T., Seakins, J. W. T., Francis, D. E. M. and Wolff, O. H. (1971). Low proline diet in type I hyperprolinaemia. Archives of Disease in Childhood, 46, 72.

Holt, L. E., Jr. (1967). Amino acid requirements of infants. Current Therapeutic Research, 9, 149.

Jarnum, S., Jeejeebhoy, K. N., Borkar, A. V., and Westergaard, H. (1969). Nitrogen balance during parenteral administration of racemic and L-isomeric amino acids. Scandinavian fournal of Gastroenterology, 4, Suppl. 3, 35.
Johnston, I. D. A. (1972). The role of parenteral nutrition in surgical care. Annals of Royal College of Surgeons of England, 50, 196.

Johnston, I. D. A., Tweedle, D., and Spivey, J. (1972). Intravenous feeding after surgical operation. In Parenteral Nutrition, p. 189. Ed. by A. W. Wilkinson. Churchill Livingstone, Edinburgh and London.

Jürgens, P., and Dolif, D. (1968). Die Bedeutung nichtessentieller Aminosäuren für den Stickstoffhaushalt des Menschen unter parenteraler Ernährung. Klinische Wochenschrift, 46, 131.

Larsen, V., and Brockner, J. (1969). The value of parenteral nutrition in patients with gastrointestinal diseases. Scandinavian fournal of Gastroenterology, 4, Suppl. 3, 41.

Logan, R. W., and Tweedie, A. K. (1973). An evaluation of the SMA 12/Micro Autoanalyzer in the clinical biochemistry laboratory. Clinica Chimica Acta, 44, 73.

Milne, M. D. (1968). Pharmacology of amino acids. Clinical Pharmacology and Therapeutics, 9, 484.

Monnens, L., Trijbels, F., Van Galen, M., Henrichs, Y., and Baars, P. (1973). Complications of intravenous feeding. Lancet, 1, 1116.

Rose, W. C. (1949). Amino acid requirements of man. Federation Proceedings, 8, 546.

Rubinstein, H. M., and Pryce, J. D. (1959). The colorimetric estimation of alpha-amino nitrogen in tissue fluids. Fournal of Clinical Pathology, 12, 80.

Sturman, J. A., Gaull, G., and Raiha, N. C. R. (1970). Absence of cystathionase in human fetal liver: is cystine essential ? Science, $169,74$.

Tweedle, D. E. F., Spivey, J., and Johnston, I. D. A. (1971). A comparison of the effect of some currently available mixtures of amino-acids on postoperative metabolism. (Abst.) British fournal of Surgery, 58, 855.

van de Kamer, J. H., Huinink, H. ten B., and Weyers, H. A. (1949). Rapid method for the determination of fat in feces. Fournal of Biological Chemistry, 177, 347.

Wilmore, D. W., Groff, D. B., Bishop, H. C., and Dudrick, S. J. (1969). Total parenteral nutrition in infants with catastrophic gastrointestinal anomalies. Fournal of Pediatric Surgery, 4, 181.

Correspondence to Dr. R. W. Logan, Department of Biochemistry, Royal Hospital for Sick Children, Glasgow G3 8SJ. 